\title{
Simulation-based Projections of Crop Management and Gross Margin Variance in Contrasting Regions of Southwest Germany
}

\author{
Phillip S. Parker (Corresponding author) \\ Institute of Farm and Agribusiness Management \\ Justus-Liebig-University, Gießen Senckenbergstraße 3, 35390 Gießen, Germany \\ Now at: Institute of Landscape Systems Analysis \\ Liebniz Centre for Agricultural Landscape Research (ZALF) \\ Eberswalder strasse 84, 15374 Müncheberg, Germany \\ Tel: 33-4328-2179Ｅ-mail: phillip.parker@zalf.de
}

Evelyn Reinmuth

Institute for Farm Management, Section Production Theory and Resource Economics (410a)

University of Hohenheim, Schloß-Osthof-Südflügel, 70593 Stuttgart, Germany

Tel: 49-0711-4592-2549_Email: evelyn_reinmuth@uni-hohenheim.de

Joachim Ingwersen

Institute of Soil Science and Land Evaluation (310)

University of Hohenheim, Emil-Wolff-Str. 27, 70593 Stuttgart, Germany

Tel: 49-0711-4592-3675Ｅmail: jingwer@uni-hohenheim.de

Petra Högy

Institute of Landscape and Plant Ecology (320),

University of Hohenheim, August-von-Hartmann-Strasse 370599 Stuttgart, Germany

Tel: 49-0711-4592-3819Ｅmail: Petra.Hoegy@uni-hohenheim.de 


\title{
Eckart Priesack
}

Helmholtz-Zentrum München, German Research Center for Environmental Health, Institute of Soil Ecology, Ingolstädter Landstr. 1, 85764 Oberschleissheim, Germany

Tel: 49-893-187-3354Ｅmail: priesack@helmholtz-muenchen.de

\author{
Hans-Dieter Wizemann \\ Institute of Physics and Meteorology (120) \\ University of Hohenheim, Garbenstrasse 30, 70593 Stuttgart, Germany
}

Tel: 49-0711-4592-2144Ｅmail: hans-dieter.wizemann@uni-hohenheim.de

Joachim Aurbacher

Institute of Farm and Agribusiness Management

Justus-Liebig-University Gießen, Senckenbergstraße 3, 35390 Gießen, Germany

Tel: 49-641-993-7260Ｅmail: joachim.aurbacher@agrar.uni-giessen.de

Received: July 12, 2014 Accepted: July 26, 2014

doi:10.5296/jas.v3i1.5956 URL: http://dx.doi.org/10.5296/jas.v3i1.5956

\begin{abstract}
Crop simulation is a modern tool used to mimic ordinary and extraordinary agriculture systems. Under the premise of continuing foreseeable climatic shift we combine adaptive field-level management decisions with their effects on crop performance. Price projections are used to examine yield and price effects on gross margins of the predominant crops in two specific regions of Southwest Germany into the coming decades. After calibration and validation to historic records, simulated future weather is used to explore how farmer behavior and performance of wheat, barley, rapeseed and maize could develop under anticipated global change. This development is examined based on a comparison of historic and projected gross margin variance. Simulations indicate that when yield levels increase, the relative variability of gross margins may decline in spite of some increasing variability of yields. The coefficient of variance of gross margins decreases even more due to the independence of price and yield fluctuations. This shows how the effects of global change on yields could be offset by economic conditions.
\end{abstract}

Keywords: Integrated modelling, Yield forecasts, Simulated gross margins, Global change, 
Agricultural adaptation, Risk.

\section{Introduction}

In a market economy, profitability is a crucial condition of farm management efficacy and at least short-term sustainability. How climate change might affect the comparative profitability of different crops in a given region is thus an important question in agricultural research and to farmers directly. To have more comprehensive projections of economic and ecological conditions under which future agriculture will be practiced is to be better able to plan for and react to likely circumstances. To this end, integrated crop and farm-agent modeling have become important tools for exploring how the environment, technology and human behavior interact and drive development in agricultural systems. The aim of this paper is to compare past and future gross margin fluctuations using integrated simulation models.

\subsection{Field-Level Simulation}

This paper is based on simulated cropping of winter wheat (Triticum aestivum L.), spring and winter barley (Hordeum vulgare L.) and silage maize (Zea mays L.) using CERES (Jones and Kiniry, 1986) and winter rapeseed (Brassica napus L.) with GECROS (Xinyou and van Laar, 2005) as embedded in the soil-plant-atmosphere model EXPERT-N (Priesack, 2006). These crops are of major economic importance, covering almost half of Europe's arable land, and three-fourths of that in Germany (Eurostat, 2013).

Governing crop simulations is the agent-based model FARMACTOR (Aurbacher et al., 2013). Performance of cropping actions, including planting and harvesting, is based on the simulated farmer reacting at a daily time interval to conditions in the field. Annual management decisions are also dependent on learning from historic patterns that generate expectations and steer behavior. For this paper a genetic algorithm is used to iteratively calibrate the timing of management actions to observed records, as well as fuzzy logic imitating a farmer's decision-making process. Management and crop performance measures are validated to historic records which then lead to projections into the future using simulated weather based on anticipated climate change.

\subsection{Risk in Agricultural Production}

Weather is largely responsible for the annual variability of agricultural production. It represents the uncertainty associated with production and makes outcomes difficult to predict compared to industrial production. Risk, the undesirable part of uncertainty (Knight, 1921) is intrinsic to agricultural production and therefore unavoidable (Hardaker et al., 2004). Climate change can be expected to alter farm income in both ways and at different magnitudes than previously experienced. It is the farmer's challenge to balance risk and return, given personal willingness to withstand a certain range of outcomes (Harwood et al., 1999, Hardaker et al., 2004). Risk has been found together with learning to be the major driver of adaptation (Baerenklau, 2005). As knowledge is gathered over time, information about the known part of uncertainty changes, meaning that adaptation is a continuous process of change over time.

Herein is a proposition of what might happen with the variability, and hence level of risk, of 
several field crops under a changing climate. Simulations at the field level and with an artificial single-crop choice leave us with the interpretation of the gross margin variability under "optimal choice" conditions where management, especially planting, is only constrained by weather, both daily and long-term patterns. This provides a foundation upon which adaptive cropping decisions may be based in the future.

\section{Methods and Materials}

\subsection{Study Areas}

The Kraichgau and Schwäbische Alb are two distinct regions in Baden-Württemberg, Southwest Germany. The former is a fertile, intensely cropped region along the Rhine River while the latter, $100 \mathrm{~km}$ to the Southeast, is a relatively harsh plateau of predominant extensive agricultural use (Gayler et al., 2014). The study location in the Kraichgau lies in Karlsruhe Rural District (Landkreis) while the Central Schwäbische Alb location is in Alb-Donau-Kreis. Average yields of the five simulated crops in these two districts are the basis for comparison of the respective study areas. Simulated field cropping on a hypothetical farm in each region, as contrasting agricultural environments, presents a broad perspective on climate-driven farm management and crop performance in the foreseeable future. A map below portrays the study areas and key locations (Appendix 1).

\subsection{Calibration/Validation Data}

Calibration data for EXPERT-N, including soil parameters, daily weather and plant performance was derived from winter wheat, silage maize and winter rapeseed grown on experimental fields near Pforzheim in the Kraichgau and Nellingen in the Schwäbische Alb during the 2009-2011 growing seasons (Ingwersen et al., 2011, Wizemann et al., 2014). Spring and winter barley data were provided by Baden-Württemberg state variety trial stations (LTZ Augustenberg, 2013), augmented with data from the German Weather Service (DWD, 2012a) and the soil map of the Federal State of Baden-Württemberg (LGRB, 1997). To account for breeding progress in field crops, the calibrated value of one growth parameter per crop is shifted each simulation year (Parker et al., submitted).

The DWD maintains a network of weather and phenological observatories (DWD, 2012b) in close enough proximity to allow derivation of causal relationships between them (Menzel, 2013). DWD weather at Eppingen was used for planting date calibration in the Kraichgau, together with the nearest phenology station with complete data - Oberderdingen (for all crops except winter barley, for which the paucity of data led to choosing Helmstadt). In the Schwäbische Alb, Merklingen weather and Nellingen phenology were chosen for calibration. Time periods outside of the calibration period are available for validation of simulated planting dates, while harvest date and yield, calibrated to other data, are validated to phenological records and district yields for the whole period 1981-2010. For barley, when DWD phenological records are not existent, planting and harvest dates from various LTZ trials sites are used for validation. 


\subsection{Price Assumptions}

To generate comparable product price series, we use a 20 -year price index from the German Statistical Office (DESTATIS, 2013) from 1994 to 2013, converted to absolute (nominal) prices $p_{t}$ with base year (2005) prices from the Federal Ministry of Food and Agriculture (BMELV, 2013) for the wheat, fodder (winter) barley, malting (spring) barley and oilseeds (winter rapeseed). To account for a geometric price trend, we estimate the model $\ln \left(p_{t}\right)=\mu+\beta \times t+\varepsilon$, results of which for each crop are given in Table 1 . The trend parameters are only in part significantly different from zero, but still they are a better estimation for the trend than assuming no trend. This allows an annual calculation of $p_{t /} \hat{p}_{\mathrm{t}}$,

where $\hat{p}_{\mathrm{t}}$ is the model-estimated price at time $t$. These ratios can be interpreted as the annual divergence from the estimated trend, in which we are especially interested. For the past, these divergence values are multiplied by the mean of the observed prices to obtain a fluctuating, but de-trended price series. For the future scenarios, we use the five-year average of prices 2009-2013 as a base, multiplied by a randomly resampled series of the annual divergences. Silage maize is the exception as there is no long-term market price series available, only very local markets started to evolve with the advent of biogas plants. Thus we do not apply the above approach given to silage maize, but instead use a constant price of $28 €$ per ton of fresh matter, as given by KTBL (2012). This accounts for the tendency to make multi-year contracts at constant prices even when local silage maize markets do exist.

The advantage of the above approach is to abstract from price trends and focus on the variability of prices, which, together with yield variation comprise the majority of profitability fluctuations. However, we implicitly assume that the magnitude of the price fluctuations stay constant, which may or may not be the case.

Table 1. Estimated model parameters from 1993-2012 prices, with intercept M and trend b, of a geometric price trend for each crop

\begin{tabular}{|l|c|c|c|c|}
\hline & Wheat & Winter barley & Spring barley & Rapeseed \\
\hline $\mathrm{M}$ & -27.89 & -25.39 & -11.07 & -61.94 \\
\hline $\mathrm{b}$ & 0.01635 & 0.01505 & 0.007989 & 0.03362 \\
\hline $\mathrm{p}$-value(b) & 0.107 & 0.125 & 0.409 & 0.000 \\
\hline
\end{tabular}

Source: Own calculations based on DESTATIS (2013)

Total variable input costs per hectare are maintained constant at their crop-specific 1993-2012 averages (KTBL, 2012) for calculation of both historic and future gross margins.

\subsection{Model Calibration}

EXPERT-N was calibrated according to methods in Aurbacher et al. (2013). Dynamic genetic parameters were developed to replicate how wheat and barley breeding has produced an 
increasing number of grains per plant (Ahlemeyer and Friedt, 2012, Parker et al., submitted), while changing initial leaf nitrogen concentration in rapeseed is used to reproduce the observed yield trend. Silage maize yields have been relatively steady in the two study areas and the complexity of genetic factors involved led to an assumption of static genetic parameters for this study ${ }^{1}$.

\subsubsection{Calibration of Field Management}

FARMACTOR conducts daily integration of EXPERT-N with database soil and weather records and internal management decision-making, subject to "learning", herein represented by the simulated farmer building expectations based on a 10-year moving average of environmental factors. These are 1-week average soil temperatures for spring crops ("learning soil-temp") and remaining cumulative air temperatures for fall-planted crops ("learning GDD”) (Aurbacher et al., 2013). Field-specific soil properties determine the moisture level corresponding to a favorable response to action, and at which traffic and tillage can be withstood without the long-term damage of compaction (Rotz and Harrigan, 2005). The model's crop rotation algorithm (Aurbacher and Dabbert, 2011) was omitted to simplify the extraction of annual performance measures of each crop and to determine planting and harvest dates based solely on daily crop, soil and weather conditions. To accommodate the lack of crop rotation, soil nutrient values are reset each year.

\subsubsection{Planting}

Learning from several years of weather designates planting periods each year, during which daily soil moisture and temperature, air temperature(s) and precipitation are action triggers. The fall planting window begins when the year's (learning-based) expected remaining growing degree days (GDD) reaches a certain minimum threshold, or "trigger". Spring planting of barley and maize begins when the next week's expected mean soil temperature is above a crop-specific value. Within their respective allotted time periods, planting of each crop is associated with a set of additional triggers, all of which include soil moisture (volumetric water content of the upper $30 \mathrm{~cm}$ ) as an indicator of trafficability. Additionally, the weather over several days is evaluated by the simulated farmer to build short-term expectations that guide behavior (Aurbacher et al., 2013). This is a pre-period minimum temperature where spring planting is only possible when the air is consistently warm enough that it is unlikely that temperatures will subsequently fall to crop-damaging levels. Following Oleson et al. (2012) maximum daily temperature values were added as criteria for autumn sowing. In addition, maximum temperatures over a 3-day pre-period were included. Our justification of this mechanism is that excessive temperatures after planting are likely to result in overdevelopment before winter dormancy, while also being conducive to insect, pathogen and weed growth. Farmers are generally reluctant to work a field during rain, justifying a maximum for daily precipitation. However, the daily resolution of weather data does not account for partial days without precipitation that would allow work.

\footnotetext{
${ }^{1}$ Crop simulation model calibration details are omitted from this paper, but available from the authors upon request.
} 
FARMACTOR can be run iteratively using a genetic algorithm to minimize the error (RMSE) between observed and simulated planting dates by altering action triggers according to an evolutionary strategy. Further, multiple behavioral paradigms can govern the timing of action: fixed triggers throughout the planting period, combinations of trigger values subject to fuzzy logic, and "shifting" triggers ${ }^{2}$ that are relaxed linearly throughout the time window. The genetic algorithm was run for thirty years, the first ten to establish learned temperature expectations and the last twenty comparing simulated to observed planting dates. To limit the necessary computational capacity, calibration was limited to ten iterations with a population of sixteen trigger combinations each, for a total of 160 model runs for each crop and location. This establishes optimal base values plus "fuzziness" ranges and amounts of daily trigger shift. Fuzzy logic proved to be the most appropriate paradigm in hind-casting planting dates in the Kraichgau. The Schwäbische Alb, however, presents a different situation where, as revealed below, shifting triggers proved more suitable.

\subsubsection{Harvest}

Harvest is subject to a set of simultaneously evaluated feasibility criteria including crop development stage, soil trafficability and daily precipitation. In seed crops a proxy for moisture content (affecting drying costs) is a combination of minimum pre-period temperature and maximum precipitation $\left(8^{\circ} \mathrm{C}\right.$ and $10 \mathrm{~mm}$ over three days).

\subsection{Implications of Risk}

This paper works with the assumption that farmers "wish to increase their wealth over time" (Pannell et al., 2000, p. 76), implying a preference for greater yields. A further assumption is that farmers in general are risk-averse and favor a less volatile yield distribution. The important point for relative profitability and risk is the artificiality of observed yields over time under a changing climate under "optimal choice conditions". Annual yields and their variance are used as "agronomic utility" parameters defining the trend distribution of each crop and serve as a reference for farmer behavior in terms of perceived gains and losses. Simulating adaptive management heuristically incorporates the consideration of risk and reward.

\section{Results and Discussion}

\subsection{Management Calibration Results}

Table 2 shows results of calibration with the genetic algorithm using fuzzy triggers in the Kraichgau and both fuzzy and shifting triggers for the Schwäbische Alb. The best target value is given along with its corresponding set of trigger values.

Table 2. Optimized planting trigger values and target (RMSE)

\begin{tabular}{|l|c|c|c|c|c|}
\hline & $\begin{array}{c}\text { Winter } \\
\text { wheat }\end{array}$ & $\begin{array}{c}\text { Winter } \\
\text { barley }\end{array}$ & $\begin{array}{c}\text { Winter } \\
\text { rapeseed }\end{array}$ & $\begin{array}{c}\text { Spring } \\
\text { barley }\end{array}$ & $\begin{array}{c}\text { Silage } \\
\text { maize }\end{array}$ \\
\hline
\end{tabular}

\footnotetext{
${ }^{2}$ Planting is subject to each trigger so that, with shifting: (min) $v \geq$ base - shift - day, and (max) $v \leq$ base + shift - day; and with fuzzy logic: the composite $t^{*}$ of $n$ triggers must exceed a given threshold of 0.5 where: $t^{*}=\left[\prod_{k=0}^{n} t_{k}\right]^{1 / p n}$ where $(\min ) \mathrm{t}=\left[\mathrm{v}-\left(\mathrm{b}-\frac{\mathrm{f}}{2}\right)\right] / \mathrm{f}$ and $(\max ) \mathrm{t}=\left[\mathrm{b}+\frac{\mathrm{f}}{2}-\mathrm{v}\right] / \mathrm{f}$ with $n$ triggers at base value $b$ and fuzzy range $f$, while $v$ is the currently simulated value. All $t \mathrm{~s}$ are truncated to be between 0 and 1 .
} 
Kraichgau - with fuzzy planting triggers

\begin{tabular}{|c|c|c|c|c|c|}
\hline Learning GDD $\left({ }^{\circ} \mathrm{C}\right)$ & 439.47 & 873.33 & \begin{tabular}{|l|}
1093.49 \\
\end{tabular} & - & - \\
\hline Learning Soil Temp. $\left({ }^{\circ} \mathrm{C}\right)$ & - & - & - & 9.06 & 12.53 \\
\hline Max. Soil Moisture (\% Vol.) & 39.69 & 31.50 & 45.78 & 35.76 & 50 \\
\hline Range $^{*}$ (\% Vol.) & 10.02 & 19.82 & 0 & 32.59 & 17.22 \\
\hline Max. Precip. (mm day $\left.{ }^{-1}\right)$ & 3.49 & 0 & 0 & 20 & 0 \\
\hline Range $^{*}\left(\mathrm{~mm}\right.$ day $\left.^{-1}\right)$ & 0.61 & 28.01 & 1.71 & 10.71 & 41.64 \\
\hline Max. Air Temp $\left({ }^{\circ} \mathrm{C}\right)$ & 19.69 & 11.78 & 18.30 & - & - \\
\hline Range ${ }^{*}\left({ }^{\circ} \mathrm{C}\right)$ & 5.57 & 0 & 2.13 & - & - \\
\hline Max. 3-Day Air Temp $\left({ }^{\circ} \mathrm{C}\right)$ & 11.73 & 25.79 & 24.13 & - & - \\
\hline Range $^{*}\left({ }^{\circ} \mathrm{C}\right)$ & 38.84 & 0 & 0.66 & - & - \\
\hline Min. GDD & 105.20 & 3000 & 1395.92 & - & - \\
\hline Range ${ }^{*}\left({ }^{\circ} \mathrm{C}\right)$ & 0 & 288.91 & 17.63 & - & - \\
\hline Min. Air Temp $\left({ }^{\circ} \mathrm{C}\right)$ & - & - & - & 6.14 & 10.17 \\
\hline Range ${ }^{*}\left({ }^{\circ} \mathrm{C}\right)$ & - & - & - & 47.34 & 36.10 \\
\hline Min. 3-Day Air Temp $\left({ }^{\circ} \mathrm{C}\right)$ & - & - & - & 0.53 & 1.69 \\
\hline Range $^{*}\left({ }^{\circ} \mathrm{C}\right)$ & - & - & - & 0.46 & 14.11 \\
\hline RMSE (days) & 9.93 & 3.42 & 9.75 & 9.69 & 5.15 \\
\hline
\end{tabular}

Schwäbische Alb - with fuzzy planting triggers

\begin{tabular}{|c|c|c|c|c|c|}
\hline Learning GDD $\left({ }^{\circ} \mathrm{C}\right)$ & 1000 & 734.36 & 794.29 & - & - \\
\hline Learning Soil Temp. $\left({ }^{\circ} \mathrm{C}\right)$ & - & - & - & 4.97 & 2.73 \\
\hline Max. Soil Moisture (\% Vol.) & 48.05 & 46.29 & 42.05 & 59.79 & 43.46 \\
\hline Range $^{*}(\%$ Vol.) & 3.96 & 4.72 & 5.00 & 0.00 & 21.89 \\
\hline Max. Precip. (mm day $\left.{ }^{-1}\right)$ & 0.49 & 3.01 & 0.29 & 4.24 & 5.75 \\
\hline $\operatorname{Range}^{*}\left(\mathrm{~mm}\right.$ day $\left.^{-1}\right)$ & 3.32 & 2.87 & 4.03 & 17.62 & 43.46 \\
\hline Max. Air Temp $\left({ }^{\circ} \mathrm{C}\right)$ & 7.00 & 8.31 & 15.00 & - & - \\
\hline Range ${ }^{*}\left({ }^{\circ} \mathrm{C}\right)$ & 0.23 & 0.39 & 1.54 & - & - \\
\hline Max. 3-Day Air Temp $\left({ }^{\circ} \mathrm{C}\right)$ & 7.77 & 26.55 & 13.69 & - & - \\
\hline Range ${ }^{*}\left({ }^{\circ} \mathrm{C}\right)$ & 5.00 & 1.64 & 0.00 & - & - \\
\hline Min. Air Temp $\left({ }^{\circ} \mathrm{C}\right)$ & - & - & - & 8.96 & 14.95 \\
\hline Range $\left({ }^{\circ} \mathrm{C}\right)$ & - & - & - & 42.83 & 13.12 \\
\hline Min. 3-Day Air Temp $\left({ }^{\circ} \mathrm{C}\right)$ & - & - & - & 0.00 & 14.91 \\
\hline Range ${ }^{*}\left({ }^{\circ} \mathrm{C}\right)$ & - & - & - & 50.00 & 21.89 \\
\hline RMSE (days) & 8.84 & 4.11 & 12.65 & 7.90 & 7.25 \\
\hline
\end{tabular}

Schwäbische Alb - with shifting planting triggers

\begin{tabular}{|c|c|c|c|c|c|}
\hline Learning GDD $\left({ }^{\circ} \mathrm{C}\right)$ & 699.61 & 710.61 & 1000 & - & - \\
\hline Learning Soil Temp. $\left({ }^{\circ} \mathrm{C}\right)$ & - & - & - & 0.00 & 11.03 \\
\hline Max. Soil Moisture (\% Vol.) & 44.90 & 35.68 & 42.01 & 24.55 & 14.24 \\
\hline Shift $^{* *}\left(\%\right.$ Vol. day $\left.{ }^{-1}\right)$ & 0.13 & 0.34 & 0.10 & 0.74 & 0.88 \\
\hline Max. Precip. $\left(\mathrm{mm}\right.$ day $\left.^{-1}\right)$ & 2.97 & 1.59 & 0.33 & 0.82 & 15.79 \\
\hline Shift $^{* *}\left(\mathrm{~mm}\right.$ day $^{-1}$ day $\left.^{-1}\right)$ & 0.48 & 0.00 & 0.28 & 0.16 & 0.39 \\
\hline Max. Air Temp. $\left({ }^{\circ} \mathrm{C}\right)$ & 24.58 & 10.00 & 0.00 & - & - \\
\hline Shift $^{* *}\left({ }^{\circ} \mathrm{C}\right.$ day $\left.^{-1}\right)$ & 0.28 & 0.29 & 30.00 & - & - \\
\hline Max. 3-Day Air Temp. $\left({ }^{\circ} \mathrm{C}\right)$ & 15.53 & 29.21 & 16.57 & - & - \\
\hline Shift $^{* *}\left({ }^{\circ} \mathrm{C} \mathrm{day}^{-1}\right)$ & 0.36 & 0.14 & 0.50 & - & - \\
\hline
\end{tabular}




\begin{tabular}{|c|c|c|c|c|c|}
\hline Min. Air Temp. $\left({ }^{\circ} \mathrm{C}\right)$ & - & - & - & 17.89 & 8.22 \\
\hline Shift $^{* *}\left({ }^{\circ} \mathrm{C} \mathrm{day}^{-1}\right)$ & - & - & - & 0.78 & 0.97 \\
\hline Min. 3-Day Air Temp $\left({ }^{\circ} \mathrm{C}\right)$ & - & - & - & 3.88 & 2.12 \\
\hline Shift $^{* *}\left({ }^{\circ} \mathrm{C}\right.$ day $\left.^{-1}\right)$ & - & - & - & 0.28 & 0.54 \\
\hline RMSE (days) & 7.29 & 4.81 & 5.43 & 8.53 & 4.56 \\
\hline
\end{tabular}

* Range signifies the width of the transition from possible to impossible surrounding each trigger's base value which, in conjunction with all other triggers, restricts action (planting). ${ }^{* *}$ Shift is likewise the amount each trigger is relaxed each day after the beginning of the planting period. Source: Own calculations

It is apparent that the two trigger paradigms alternate in their superiority matching simulated to observed planting dates among the different crops. The decision of which ultimately to use for projections is thus a matter of validation metrics.

\subsection{Model Validation}

Validation compares the timing of simulated planting and harvest dates to DWD network and LTZ observations and simulated yields to district averages. The model was run for the five crops 1970-2010 (the first ten years a warm-up for expectation building/learning) so that outside of the calibration period planting dates can be validated for the harvest years 1981-1990 for wheat, rapeseed and maize planting dates, likewise 1991-2010 for the two barley crops (because of the different data availability). Table 3 shows validation results for planting dates at both locations.

Table 3. Validation measures of fit for simulated planting dates by crop and location

\begin{tabular}{|l|r|r|c|}
\hline & $\begin{array}{c}\text { Kraichgau } \\
\text { fuzzy triggers }\end{array}$ & $\begin{array}{c}\text { Schwäbische Alb } \\
\text { fuzzy triggers }\end{array}$ & $\begin{array}{c}\text { Schwäbische Alb } \\
\text { shifting triggers }\end{array}$ \\
\hline Winter wheat (1981-1990) \\
\hline Correlation coefficient & 0.52 & 0.09 & 0.54 \\
\hline RMSE (days) & 9.43 & 8.54 & 8.41 \\
\hline Bias (days) & -7.23 & -2.1 & -6.1 \\
\hline Winter barley (1991-2010) \\
\hline Correlation coefficient & 0.48 & -0.50 & 0.48 \\
\hline RMSE (days) & 12.74 & 11.52 & 7.29 \\
\hline Bias (days) & -1.03 & -3.4 & -5.1 \\
\hline Spring barley (1991-2010) & \\
\hline Correlation coefficient & 0.12 & 0.15 & 0.64 \\
\hline RMSE (days) & 14.45 & 26.02 & 15.20 \\
\hline Bias (days) & 1.65 & -15.8 & -0.7 \\
\hline Winter rapeseed (1981-1990) \\
\hline Correlation coefficient & 0.33 & 0.12 & -0.25 \\
\hline RMSE (days) & 13.28 & 13.86 & 5.53 \\
\hline Bias (days) & -10.40 & 10.9 & 0.6 \\
\hline Silage maize (1981-1990) & & \\
\hline Correlation coefficient & 0.37 & 0.12 & \\
\hline
\end{tabular}




\begin{tabular}{|l|r|r|r|}
\hline RMSE (days) & 8.03 & 46.35 & 13.87 \\
\hline Bias (days) & -2.20 & 45.90 & 12.40 \\
\hline
\end{tabular}

Source: Own calculations

Functioning at fine tempo-spatial resolution FARMACTOR produces accurate predictions of planting date, especially compared to coarser models (Waha et al., 2012). Correlation coefficient, RMSE and bias are chosen measures of the accuracy of simulated management, how well the model captures the underlying agronomic and behavioral principals. Considering the three measures together it was decided to proceed with shifting triggers in the Schwäbische Alb while fuzzy triggers were utilized in the Kraichgau.

Next, simulated crop performance for harvests years 1981-2010 is validated to Karlsruhe and Alb-Donau District yields for the Kraichgau and Schwäbische Alb, repectively, and the most nearby phenological records of harvest dates (see section 2.2.). Table 4 provides metrics on the accuracy of simulated harvest date and yield.

Table 4. Validation period measures of fit for simulated harvest dates and yield by crop and location (harvest years 1981-2010)

\begin{tabular}{|c|c|c|c|c|}
\hline & \multicolumn{2}{|c|}{ Kraichgau } & \multicolumn{2}{|c|}{ Schwäbische Alb } \\
\hline & $\begin{array}{c}\text { Harvest } \\
\text { (day of year) }\end{array}$ & $\begin{array}{l}\text { Yield } \\
\left(\mathrm{dt} \mathrm{ha}^{-1}\right)\end{array}$ & $\begin{array}{c}\text { Harvest } \\
\text { (day of year) }\end{array}$ & $\begin{array}{l}\text { Yield } \\
\left(\mathrm{dt} \mathrm{ha}^{-1}\right)\end{array}$ \\
\hline \multicolumn{5}{|l|}{ Winter wheat } \\
\hline Correlation coefficient & 0.78 & 0.52 & 0.83 & 0.86 \\
\hline RMSE & 12.73 & 12.37 & 9.79 & 6.18 \\
\hline Bias & -8.10 & -1.79 & -10.28 & 0.28 \\
\hline \multicolumn{5}{|l|}{ Winter barley } \\
\hline Correlation coefficient & 0.57 & 0.52 & 0.69 & 0.72 \\
\hline RMSE & 10.18 & 7.88 & 8.67 & 6.17 \\
\hline Bias & -1.40 & -3.43 & 0.03 & 2.33 \\
\hline \multicolumn{5}{|l|}{ Spring barley } \\
\hline Correlation coefficient & 0.65 & 0.55 & 0.26 & 0.64 \\
\hline RMSE & 16.09 & 11.22 & 11.17 & 11.55 \\
\hline Bias & -13.50 & 0.16 & 2.84 & 9.19 \\
\hline \multicolumn{5}{|l|}{ Winter rapeseed } \\
\hline Correlation coefficient & 0.51 & 0.52 & 0.78 & 0.50 \\
\hline RMSE & 11.40 & 14.87 & 8.19 & 8.14 \\
\hline Bias & 9.01 & 0.14 & -5.63 & 1.17 \\
\hline \multicolumn{5}{|l|}{ Silage maize } \\
\hline Correlation coefficient & -0.24 & 0.26 & -0.26 & 0.17 \\
\hline RMSE & 21.96 & 75.48 & 23.65 & 59.32 \\
\hline Bias & -6.60 & 49.61 & 17.13 & -33.14 \\
\hline
\end{tabular}

Source: Own calculations 
Compared to similar multiple-year simulation endeavors such as Palosuo et al. (2011), validation accuracy is satisfactory and supports the following projections of how agricultural production at the two locations will develop in the coming decades. The following projections of field management and crop performance utilize WETTREG 2010 simulated future weather scenarios (Kreienkamp et al., 2010) at Eppingen and Merklingen based on historic records and assuming IPCC scenario A1B (IPCC, 2007).

\subsection{Projections}

Projections until the year 2031 were completed for the simulated farms at both locations. Three runs for each were performed using separate realizations of the same WETTREG scenarios (Kraichgau: Eppingen 25002-11, 25002-77 and 25002-99; Schwäbische Alb: Merklingen 2814-33, 2814-55 and 2814-99). Linear regression function intercept and slope for planting, harvest and yield averages from the three future runs are presented in Table 5.

Table 5. Projected management and crop performance statistics 2012-2031 (harvest years)

\begin{tabular}{|c|c|c|c|c|c|}
\hline & $\begin{array}{l}\text { Winter } \\
\text { wheat }\end{array}$ & $\begin{array}{l}\text { Winter } \\
\text { barley }\end{array}$ & $\begin{array}{l}\text { Spring } \\
\text { barley }\end{array}$ & $\begin{array}{c}\text { Winter } \\
\text { rapeseed }\end{array}$ & $\begin{array}{l}\text { Silage } \\
\text { maize }\end{array}$ \\
\hline \multicolumn{6}{|c|}{ Kraichgau (with fuzzy planting triggers) } \\
\hline Planting -intercept (day) & 286.21 & 254.90 & 81.72 & 255.55 & 119.13 \\
\hline -trend $\left(\right.$ days $\left.\mathrm{yr}^{-1}\right)$ & +0.52 & +0.43 & -0.36 & +0.36 & -0.11 \\
\hline \begin{tabular}{|l|l|} 
Harvest -intercept & (day) \\
\end{tabular} & 200.96 & 212.92 & 200.47 & 209.62 & 290.81 \\
\hline -trend $\left(\right.$ days $\left.\mathrm{yr}^{-1}\right)$ & -0.63 & -0.28 & -0.35 & -0.37 & -0.79 \\
\hline \begin{tabular}{l|l} 
Yield -intercept & $\left(\mathrm{t} \mathrm{ha}^{-1}\right)$ \\
\end{tabular} & 5.523 & 5.855 & 5.939 & 5.866 & 70.032 \\
\hline -trend $\left(\mathrm{t} \mathrm{ha}^{-1} \mathrm{yr}^{-1}\right)$ & +0.075 & +0.026 & +0.052 & -0.066 & -0.181 \\
\hline \multicolumn{6}{|c|}{ Schwäbische Alb (with shifting planting triggers) } \\
\hline Planting -intercept (day) & 269.52 & 260.25 & 89.11 & 231.46 & 123.20 \\
\hline -trend $\left(\right.$ days $\left.\mathrm{yr}^{-1}\right)$ & +0.10 & +0.08 & -0.05 & +0.14 & -0.09 \\
\hline Harvest -intercept (day) & 226.12 & 216.67 & 231.75 & 219.73 & 288.78 \\
\hline -trend $\left(\right.$ days $\left.\mathrm{yr}^{-1}\right)$ & -1.02 & -0.72 & -0.16 & -0.60 & -1.05 \\
\hline \begin{tabular}{l|l} 
Yield -intercept & $\left(\mathrm{t} \mathrm{ha}^{-1}\right)$ \\
\end{tabular} & 8.056 & 7.167 & 6.354 & 4.378 & 47.840 \\
\hline -trend $\left(\mathrm{t} \mathrm{ha}^{-1} \mathrm{yr}^{-1}\right)$ & +0.009 & +0.086 & +0.036 & +0.029 & +0.039 \\
\hline
\end{tabular}

Source: Own calculations

\subsubsection{Planting}

According to model projections for the Kraichgau, winter crops will be sown about one day later for every two to three years into the future. Sowing of spring barley should occur earlier at a similar rate, while sowing of maize in spring should advance slower, about one day every nine years. Projections for the Schwäbische Alb also show gradually later sowing in autumn and earlier planting in spring.

\subsubsection{Harvest}

The warmer temperatures in simulated future weather drives harvest dates earlier in all crops, at both locations, between roughly one to two days every three years in the Kraichgau. Harvests in the Schwäbische Alb, notwithstanding spring barley, occur earlier at an even faster rate, 
wheat and maize maturing more than one day sooner per year. While the simulated future growing season, e.g. time between spring and fall frosts, is expanding, warmer temperatures result in crops ripening faster so that no advantage can be gained from the extended season. This would, however, likely be counteracted with the use of later-ripening, more biomass-generating cultivars.

Overall, projected phenological trends appear plausible. However, at some point the climate-induced changes, e.g. toward earlier harvests, should lead to structural change in cropping methods such as greater appearance of previously uncommon crop rotations. Further research will focus on this possibility.

\subsubsection{Yields}

Kraichgau simulations project a slight increase in yields for all crops except rapeseed and silage maize. In contrast are the increasing yields of all crops in the Schwäbische Alb. Aurbacher et al. (2013), modeling the nearby Schwäbische Alb, projected negative trends in wheat and maize yields. The process-based inclusion breeding progress, not included in the latter, demonstrates one way in which the detrimental effects of climate change may be mitigated (Parker et al. submitted). Angulo et al. (2013) project decreasing yields for five major European crops, based solely on climate change. However, when technological change and $\mathrm{CO}_{2}$ fertilization are included their projections were more optimistic.

\subsection{Gross margins}

Gross margins serve as a basic measure of profitability and their variance can give an impression of associated risk. Simulated yields from 1992-2011 are multiplied by the de-trended historic producer price in each year before the average variable input cost over the same period is subtracted to derive a gross margin for each year. The coefficient of variation of gross margins over this period serves as the measure of the historic level of risk in each crop and study location.

For the future, yield results from the three simulated weather realizations are multiplied by year-specific modeled prices, minus per-hectare input costs (section 2.3) to derive projected gross margins. These are shown in Figure 1 together with simulated historic gross margins for each crop in the Schwäbische Alb, (Kraichgau in Appendix 2). However, their trends are not the focus of this paper as they depend largely on price trends which were purposefully removed. Input prices are kept constant, if they were not it could reduce the effects of price variability as factor prices (e.g. fertilizer) may correlate to product prices. 


\section{Ml Macrothink}

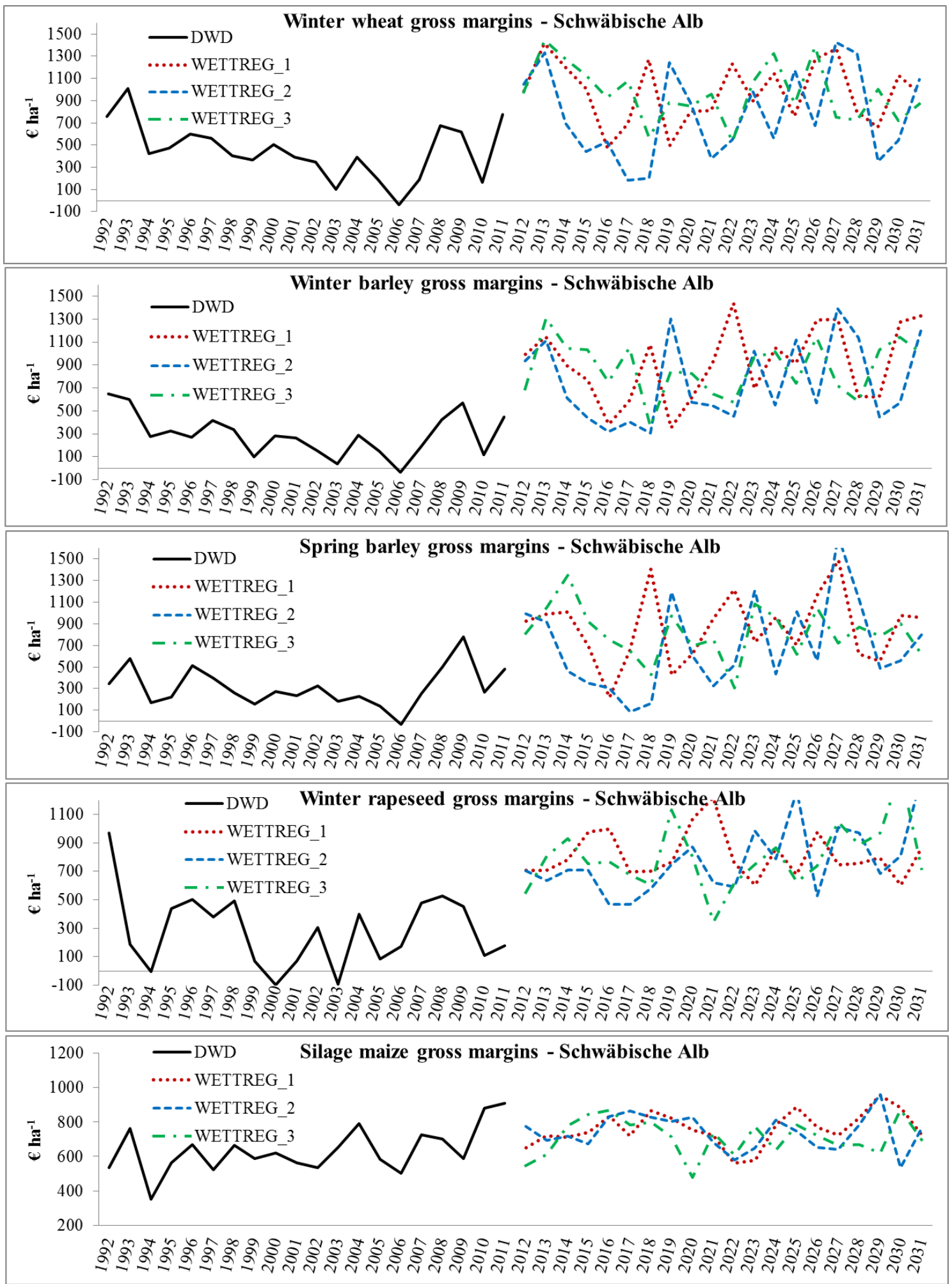

Figure 1. Simulated historic and future gross margins in the Schwäbische Alb

Source: Own calculations

For comparative metrics the individual coefficients of variation of gross margins in the three simulated future time series 2012-2031 are averaged for comparison to the twenty-year period 1992-2011 used to generate price forecasts. Table 6 offers a comparison of past and future yield 
and gross margin variation coefficients for each crop and location.

Table 6. Coefficients of variation of simulated historic and future yields and gross margins

\begin{tabular}{|c|c|c|c|c|c|}
\hline & $\begin{array}{l}\text { Winter } \\
\text { wheat }\end{array}$ & $\begin{array}{l}\text { Winter } \\
\text { barley }\end{array}$ & $\begin{array}{l}\text { Spring } \\
\text { barley }\end{array}$ & $\begin{array}{c}\text { Winter } \\
\text { rapeseed }\end{array}$ & $\begin{array}{l}\text { Silage } \\
\text { maize }\end{array}$ \\
\hline Mean historic producer price $\left(€ \mathrm{t}^{-1}\right)$ & 134.50 & 120.95 & 141.81 & 239.36 & 27.58 \\
\hline Mean forecasted producer price $\left(€ \mathrm{t}^{-1}\right)$ & 180.55 & 163.88 & 184.14 & 305.68 & 28.00 \\
\hline \multicolumn{6}{|l|}{ Schwäbische Alb } \\
\hline Historic yield $\left(\mathrm{t} \mathrm{ha}^{-1}\right)$-mean & 7.586 & 6.399 & 5.536 & 3.822 & 44.624 \\
\hline -std dev & 0.683 & 0.763 & 0.945 & 0.635 & 4.643 \\
\hline -var. coeff. & 0.090 & 0.119 & 0.171 & 0.166 & 0.104 \\
\hline Historic gross margin $\left(€ \mathrm{ha}^{-1}\right)$ - mean & 445.77 & 292.73 & 313.53 & 280.49 & 635.81 \\
\hline- std dev & 247.45 & 180.80 & 178.57 & 255.35 & 130.01 \\
\hline -var. coeff. & 0.555 & 0.618 & 0.570 & 0.910 & 0.204 \\
\hline Projected yield $\left(\mathrm{t} \mathrm{ha}^{-1}\right)$-mean & 8.148 & 8.065 & 6.734 & 4.684 & 48.249 \\
\hline -std dev & 0.469 & 0.622 & 0.628 & 0.532 & 3.683 \\
\hline -var. coeff. & 0.058 & 0.077 & 0.093 & 0.114 & 0.076 \\
\hline Projected gross margin $\left(€ \mathrm{ha}^{-1}\right)$-mean & 905.43 & 846.61 & 789.25 & 796.31 & 737.30 \\
\hline -std dev & 302.68 & 298.47 & 315.70 & 205.51 & 100.68 \\
\hline -var. coeff. & 0.345 & 0.358 & 0.410 & 0.259 & 0.137 \\
\hline \multirow{2}{*}{$\begin{array}{r}\text { Ratio of projected/historic } \\
\text { variance coefficient }\end{array}$} & 0.639 & 0.647 & 0.547 & 0.684 & 0.734 \\
\hline & 0.621 & 0.579 & 0.720 & 0.284 & 0.669 \\
\hline \multicolumn{6}{|l|}{ Kraichgau } \\
\hline Historic yield $\left(\mathrm{t} \mathrm{ha}^{-1}\right)$-mean & 6.310 & 5.293 & 5.065 & 3.600 & 48.861 \\
\hline- std dev & 0.865 & 0.653 & 1.059 & 1.342 & 6.221 \\
\hline -var. coeff. & 0.137 & 0.123 & 0.209 & 0.373 & 0.127 \\
\hline Historic gross margin $\left(€ \mathrm{ha}^{-1}\right)$ - mean & 278.07 & 162.56 & 248.48 & 246.08 & 754.46 \\
\hline -std dev & 239.28 & 164.70 & 195.47 & 475.36 & 174.18 \\
\hline -var. coeff. & 0.860 & 1.013 & 0.787 & 1.932 & 0.231 \\
\hline Projected yield $\left(\mathrm{t} \mathrm{ha}^{-1}\right)$-mean & 6.315 & 6.128 & 6.490 & 5.169 & 68.128 \\
\hline- std dev & 2.016 & 0.551 & 0.716 & 1.112 & 9.563 \\
\hline -var. coeff. & 0.319 & 0.090 & 0.110 & 0.215 & 0.140 \\
\hline Projected gross margin $\left(€\right.$ ha $\left.^{-1}\right)$-mean & 568.47 & 534.23 & 738.30 & 947.96 & 1293.91 \\
\hline -std dev & 424.05 & 241.02 & 291.01 & 380.01 & 261.40 \\
\hline -var. coeff. & 0.756 & 0.469 & 0.402 & 0.403 & 0.202 \\
\hline Ratio of projected/historic & 2.328 & 0.729 & 0.528 & 0.578 & 1.102 \\
\hline variance coefficient gross margin & 0.879 & 0.462 & 0.511 & 0.209 & 0.877 \\
\hline
\end{tabular}

Source: Own calculations 
Only winter wheat and silage maize in the Kraichgau show increasing yield variability as a result of future climatic conditions. All other crops in Kraichgau and all crops in the Schwäbische Alb experience increased yield and decreased yield variance, so that their coefficients of variation decline in the future. In the case of wheat and Kraichgau, this is in line with other work. Fuss et al. (2011) also found increasing wheat yield and yield variability in Central Europe. Kersebaum \& Nendel (2014) simulated slight increases in both absolute yield and its variability for wheat in regions throughout Germany. Here, in contrast, decreasing crop yield variances were projected. This is presumably due to the combination of the general trend towards a more favorable climate in Germany and the modelling of adaptive execution dates that mitigate some of the negative effects of climate change.

Results show that the variability (variation coefficient) of gross margins will decline even more than that of yields. Gross margin variability will decline even when yield variability has increased. This shows that price fluctuations have an additional effect on the stabilization of gross margins, even when price fluctuations are assumed to be statistically independent of yields. This is a conservative assumption, as prices and yields tend to be negatively correlated (El Benni \& Finger, 2012), and this "natural hedge" in effect further reduces gross margin variability. A part of the effect is due to the increase of future prices. On the whole, in these sample model runs, gross margin variability does not increase for any crops at either location, suggesting a comprehensive reduction in producer risk.

\section{Conclusion}

Gross margin volatility, as a measure of economic risk in agricultural production, is influenced by both price and yield variability. In the above projections, the interaction of price and yield leads to a general stabilization of gross margin fluctuation. Even in cases where yield volatility increases (here, Kraichgau wheat and maize), this is offset by the superimposition of price fluctuations. Increases in absolute price and yield levels will further amplify this effect.

Some care has to be taken as the model does not incorporate all anticipated consequences of climate change, including $\mathrm{CO}_{2}$-fertilization, extreme weather events and pest proliferation. As weather simulations continue to improve, use of new weather projections could likewise improve the robustness of the model.

Still, these results provide some insight into possible developments in the regional economic viability of field crops. This allows better estimation of future land use changes which should be reintegrated into land-atmosphere models to close the feedback loops. Further, designated decisions support systems could benefit from more detailed modelling.

\section{References}

Ahlemeyer, J., \& Friedt, W. (2012). Winterweizenerträge in Deutschland stabil auf hohem Niveau - Welchen Einfluss hat der Züchtungsfortschritt, Getreidemagazin, 17, 38-41

Angulo, C., Rötter, R., Lock, R., Enders, A., Fronzek, S., \& Ewert, F. (2013). Implication of crop model calibration strategies for assessing regional impacts of climate change in Europe. Agr. Forest Meteorol. 170, 32-46. http://dx.doi.org/10.1016/j.agrformet.2012.11.017 
Aurbacher, J., \& Dabbert, S. (2011). Generating crop sequences in land-use models using maximum entropy and Markov chains. Agr. Syst. 104, 470-489. http://dx.doi.org/10.1016/j.agsy.2011.03.004

Aurbacher, J., Parker, P. S., Calberto Sánchez, G. A., Steinbach, J., Reinmuth, E., Ingwersen, J., \& Dabbert, S. (2013). Influence of climate change on short term management of field crops - A modelling approach. Agr. Syst. 119, 44-57. http://dx.doi.org/10.1016/j.agsy.2013.04.005

Baerenklau, K. A. (2005). Toward an understanding of technology adoption: Risk, learning, and neighborhood effects. Land Econ. 81(1), 1-19. doi:10.3368/le.81.1.1

BMELV (Ed.) (2012). Statistisches Jahrbuch über Ernährung, Landwirtschaft und Forsten der Bundesrepublik Deutschland (56th ed.). Münster: Landwirtschaftsverlag. [Online] Available: http://www.bmelv-statistik.de/de/statistisches-jahrbuch/ (December 5, 2013).

DESTATIS (2013). Producer Price Index, (German) Federal Statistical Office. [Online] Available: https://www-genesis.destatis.de/genesis/online (December 5, 2013).

DWD - (German Weather Service) (2012a). Weather and Climate - Deutsche Wetterdienst -Agroclimatology. [Online] Available: http://www.dwd.de/bvbw/appmanager/bvbw/dwdwwwDesktop?_nfpb=trueand_pageLabel= dwdwww_spezielle_nutzer_landwirtschaft_agrarklimaandT134202279761205143312234gsb DocumentPath=Navigation\%2FOeffentlichkeit\%2FKlima_Umwelt\%2FKlimadatenzentren

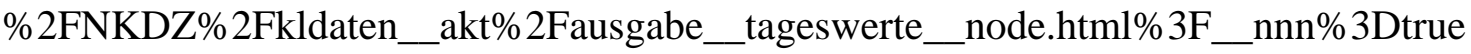
(November 29, 2012).

DWD (German Weather Service) (2012b). Weather and Climate - Deutsche Wetterdienst -Phenology. [Online] Available: http://www.dwd.de/bvbw/appmanager/bvbw/dwdwwwDesktop?_nfpb=trueand_windowLabe l=dwdwww_main_bookandT94004gsbDocumentPath=Navigation\%2FOeffentlichkeit\%2FK1 ima_Umwelt $\% 2$ FPhaenologie $\% 2 F$ produkte $\% 2$ Fjahresmelder_node.html $\% 3 \mathrm{~F} \_n n n \% 3 \mathrm{Dtr}$ ueandswitchLang=enand_pageLabel=_dwdwww_klima_umwelt_phaenologie (June 5, 2012).

El Benni, N., \& Finger, R. (2012). Where is the risk? Price, yield and cost risk in Swiss crop production (Vol. 18). Presented at the 28th Triennial Conference of the International Association of Agricultural Economists (IAAE), August 2012. Available: http://purl.umn.edu/126758 (July 10, 2014).

Eurostat, 2013. EuroStat (European Commision Statistical Databases) (2011). [Online] Available:

http://epp.eurostat.ec.europa.eu/portal/page/portal/agriculture/farm_structure/database (July 12, 2013).

Fuss, S., Havlik, P., Szolgayova, J., Schmid, E., \& Obersteiner, M. (2011). Large-Scale Modelling of Global Food Security and Adaptation under Crop Yield Uncertainty. Presented at the European Association of Agricultural Economists International Congress, August 2011. Available: http://purl.umn.edu/114347 (July 10, 2014). 
Gayler, S., Wöhling, T., Grzeschik, M., Ingwersen, J., Wizemann, H-D., Warrach-Sagi, K., Högy, P., Attinger, S., Streck, T., \& Wulfmeyer, V. (2014). Incorporating dynamic root growth enhances the performance of Noah-MP at two contrasting winter wheat field sites. Water Resour. Res. 1944-7973. http://dx.doi.org/10.1002/2013WR014634

Hardaker, J. B., Huirne, R. B., Anderson, J. R., \& Lien, G. (2004). Coping with risk in agriculture. (2nd $\quad$ ed.). Wallingford: CABI publishing. http://dx.doi.org/10.1079/9780851998312.0000

Harwood, J. L., Heifner, R., Coble, K., Perry, J., \& Somwaru, A. (1999). Managing risk in farming: concepts, research, and analysis. Washington, DC: US Department of Agriculture, Economic Research Service.

Ingwersen, J., Steffens, K., Högy, P., Warrach-Sagi, K., Zhunusbayeva, D., Poltoradnev, M., Gäbler, R., Wizemann, H.-D., Fangmeier, A., Wulfmeyer, V., Streck, T. (2011). Comparison of Noah simulations with eddy covariance and soil water measurements at a winter wheat stand. Agr. and Forest Meteorol. 151, 345-355. http://dx.doi.org/10.1016/j.agrformet.2010.11.010

IPCC, (2007). Climate Change 2007: Synthesis Report. Contribution of Working Groups I, II and III to the Fourth Assessment Report of the Intergovernmental Panel on Climate Change. IPCC, Geneva.

Jones, C. A., Kiniry, J. R. (1986). CERES-Maize, A Simulation Model of Maize Growth and Development. College Station: Texas A and M University Press.

Kersebaum, K., \& Nendel, C. (2014). Site-specific impacts of climate change on wheat production across regions of Germany using different $\mathrm{CO}_{2}$ response functions. Eur. J. Agron. 52, 22-32. http://dx.doi.org/10.1016/j.eja.2013.04.005

Knight, F. H. (1921). Risk, Uncertainty and Profit. New York: Harper and Row Publishers. (Reprinted in 1965.)

Kreienkamp, F., Enke, W., \& Spekat, A. (2010). WR2010_EH5_1_A1B: UBA-WETTREG ECHAM5/OM 20C + A1B run 1 realization run 1961-2100. World Data Center for Climate. CERA-DB "WR2010_EH5_1_A1B". [Online] Available: http://cera-www.dkrz.de/WDCC/ui/Compact.jsp?acronym=WR2010_EH5_1_A1B (March 2, 2012).

KTBL (Kuratorium für Technik und Bauwesen in der Landwirtschaft) (Ed.), (2012). Betriebsplanung Landwirtschaft, 23rd Ed., 2012/13 - KTBL-Datensammlung. Darmstadt: KTBL.

LGRB (Landesamt für Geologie, Rohstoffe und Bergbau) (1997). Bodenkarte von Baden-Württemberg 1:25 000.

LTZ Augustenberg (Landwirtschaftliches Technologiezentrum Augustenberg) (2012). Informationen für die Pflanzenproduktion. Available: http://www.ltz-augustenberg.de (February 2, 2013). 


\section{Macrothink}

Menzel, A. (2013). Plant Phenological “Fingerprints”. In: M. D. Schwartz (Ed.), Phenology: An Integrative Environmental Science (pp. 335-350). Dordrecht: Springer. http://dx.doi.org/10.1007/978-94-007-6925-0_18

Olesen, J. E., Børgesen, C. D., Elsgaard, L., Palosuo, T., Rötter, R. P., Skjelvåg, A. O., Peltonen-Sainio, P., Börjesson, T., Trnka, M., Ewert, F., Siebert, S., Brisson, N., Eitzinger, J., van Asselt, E. D., Oberforster, M., \& van der Fels-Klerx, H. J. (2012). Changes in time of sowing, flowering and maturity of cereals in Europe under climate change. Food Add. Contam.: Part A 29, 1527-1542. http://dx.doi.org/10.1080/19440049.2012.712060

Palosuo, T., Kersebaum, K. C., Angulo, C., Hlavinka, P., Moriondo, M., Olesen, J. E. Patil, R. H., Ruget, F., Rumbaur, C., Takáč, J., Trnka, M., Bindi, M., Çaldağ, B., Ewert, F., Ferrise, R., Mirschel, W., Şaylan, L., Šiška, B., \& Rötter, R. (2011). Simulation of winter wheat yield and its variability in different climates of Europe: A comparison of eight crop growth models. Euro. Jour. Agron. 35-3, 103-114. http://dx.doi.org/10.1016/j.eja.2011.05.001

Pannell D. J., Malcolm, B., \& Kingwell, R. S. (2000). Are we risking too much? Perspectives on risk in farm modeling. Agr. Econ. 23, 69-78. http://dx.doi.org/10.1111/j.1574-0862.2000.tb00084.x

Parker, P.S., Ingwersen, J., Högy, P., Priesack, E., Aurbacher, J. (Submitted). Simulating Regional Climate-adaptive Field Cropping with Fuzzy Logic Management Rules and Genetic Advance. J. Agr. Sci.

Priesack, E. (2006). Expert-N Dokumentation der Modellbibliothek. München: Hyronimus.

Rotz, C. A., \& Harrigan, T.M. (2005). Predicting suitable days for field machinery operations in a whole farm simulation. Appl. Eng. Agric. 21(4), 563-571. http://dx.doi.org/10.13031/2013.18563

Waha, K., van Bussel, L. G. J., Muller, C., \& Bondeau, A. (2012). Climate-driven simulation of global crop sowing dates. Glob. Ecol. Biogeogr. 21, 247-259. http://dx.doi.org/10.1111/j.1466-8238.2011.00678.x

Xinyou, Y., \& Van Laar, H. (2005). Crop systems dynamics: an ecophysiological simulation model for genotype-by-environment interactions, Wageningen: Wageningen Academic Pub.

Wizemann, H.D., Ingwersen, J., Högy, P., Warrach-Sagi, K., Streck, T., \& Wulfmeyer, V. (2014). Three-year observations of water vapor and energy fluxes over agricultural crops in two regional climates of Southwest Germany. Meteorol. Z., accepted for publication. 
Appendix

Appendix 1. Map of study area with key locations

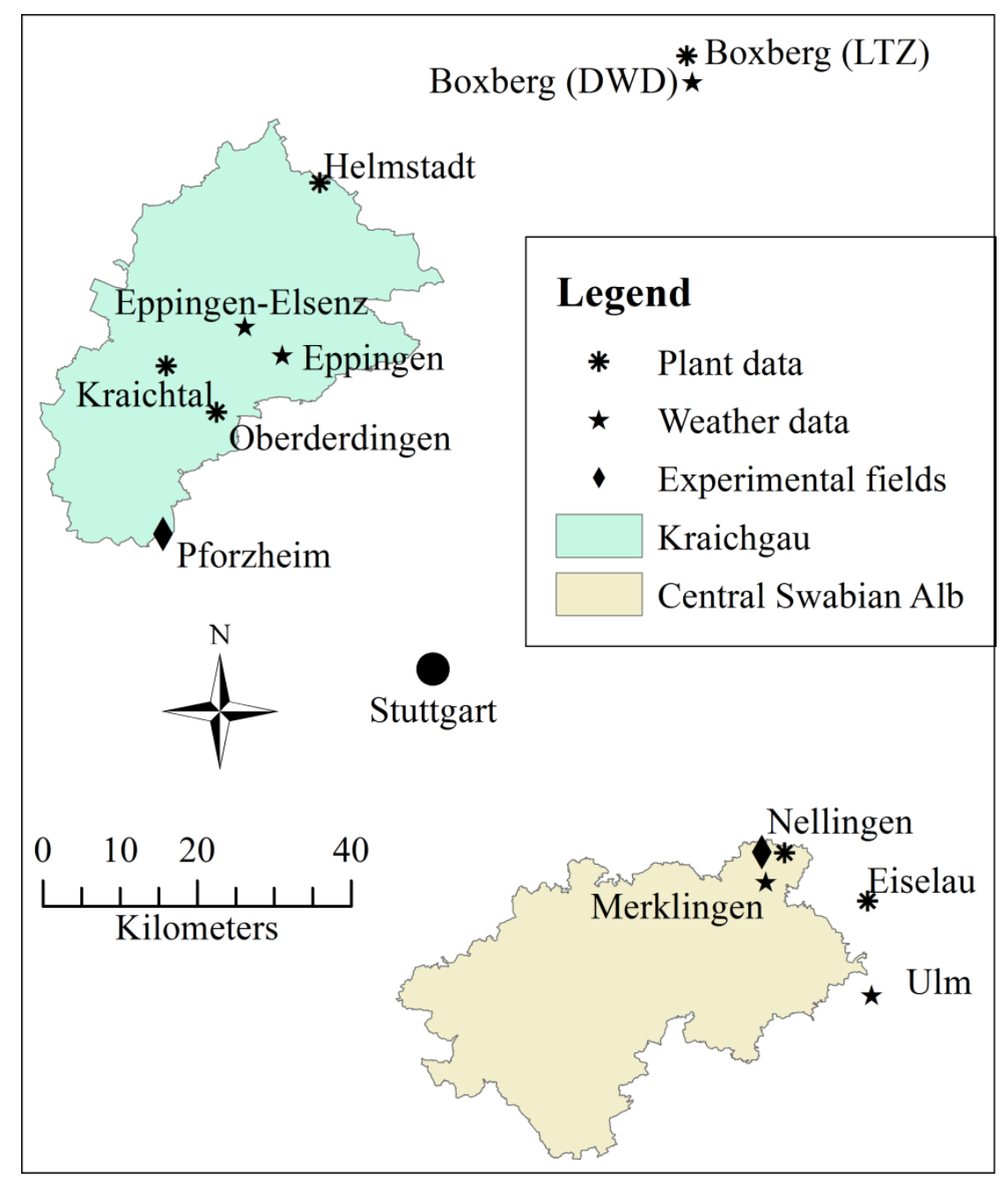


Appendix 2. Simulated historic and future gross margins in the Kraichgau

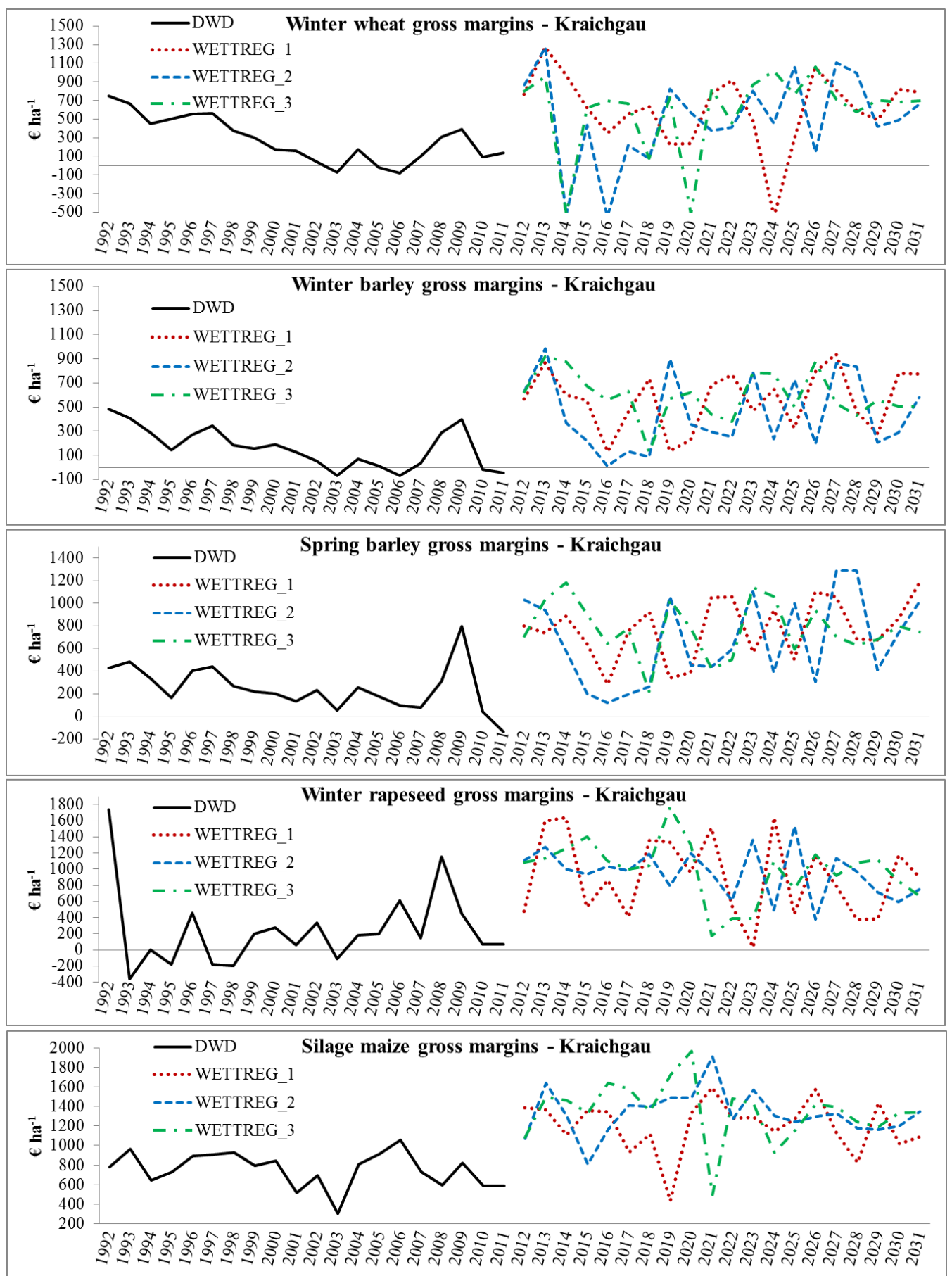

Source: Own calculations

\section{Copyright Disclaimer}

Copyright for this article is retained by the author(s), with first publication rights granted to the journal.

This is an open-access article distributed under the terms and conditions of the Creative Commons Attribution license (http://creativecommons.org/licenses/by/3.0/). 